\title{
Costal osteoid osteoma with chest pain
}

\author{
Tsuneaki Kenzaka
}

Division of General Medicine, Center for Community Medicine, Jichi Medical University School of Medicine, Shimotsuke, Tochigi, Japan

\section{Correspondence to}

Dr Tsuneaki Kenzaka, smile.kenzaka@jichi.ac.jp
To cite: Kenzaka T. BMJ Case Rep Published online: [please include Day Month Year] doi:10.1136/bcr-2013010234

\section{DESCRIPTION}

A 19-year-old man with no notable history had an acute episode of chest pain on the left side/back pain. Non-steroid anti-inflammatory drugs taken after consultation at another hospital were ineffective, and the pain persisted and intensified; therefore, he was referred to our hospital on day 2 after the onset. At the time of admission, his blood pressure was 128/64 mm Hg; pulse, regular at $66 \mathrm{bpm}$; respiration rate, 15 breaths/min; body temperature, $37.1{ }^{\circ} \mathrm{C}$; and $\mathrm{SpO}_{2}, 98 \%$ (without additional oxygen support). Heart and breathing sounds were normal, and no rash was observed; however, tenderness was observed in the fourth-fifth intercostal space on the left side of the chest/back. Blood tests, ECG, chest and rib plain radiography, chest and abdomen contrast CT and echocardiography showed no abnormal findings. A thoracic CT image showed a ring-shaped radiolucency at the fourth rib root and sclerosis of the interior (a nidus; figure 1, white arrows). Bone scintigraphy revealed accumulation at the same site. Osteoid osteoma was suspected and bone tumour resection of the fourth rib was performed. A definitive diagnosis of osteoid osteoma was made after pathological examination. Figure 2 is the pathological image. A ring-shaped radiolucency in the CT image was commensurate with the nidus of osteoid osteoma (red arrow lesions). Osteoid osteoma often occurs in the long bones of the extremities in young people, and this
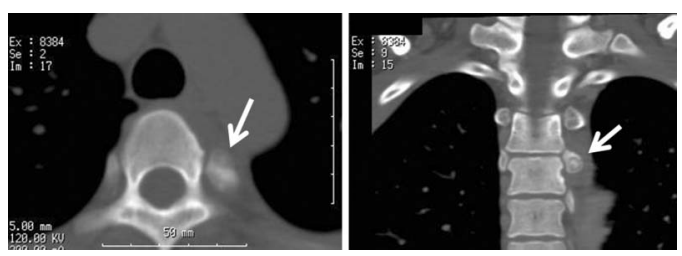

Figure 1 Thoracic CT image.

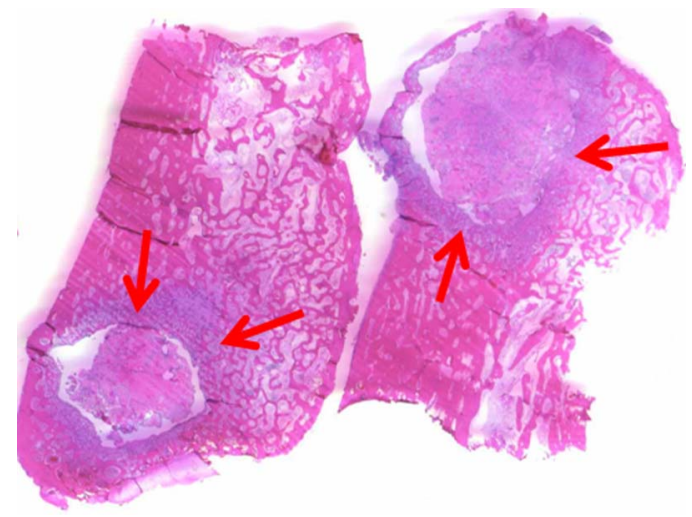

Figure 2 Pathological image.

condition is rarely observed in the chest bones ${ }^{1}$; however, this condition must be considered in the differential diagnosis of chest pain.

\section{Learning points}

A ring-shaped radiolucency in $\mathrm{CT}$ image is characteristic in osteoid osteoma.

- Osteoid osteoma in the chest bones must be considered in the differential diagnosis of chest pain.

\section{Competing interests None.}

Patient consent Obtained.

Provenance and peer review Not commissioned; externally pee reviewed.

\section{REFERENCE}

1 Thakur NA, Daniels AH, Schiller J, et al. Benign tumors of the spine. J Am Acad Orthop Surg 2012;20:715-24.

Copyright 2013 BMJ Publishing Group. All rights reserved. For permission to reuse any of this content visit http://group.bmj.com/group/rights-licensing/permissions.

BMJ Case Report Fellows may re-use this article for personal use and teaching without any further permission.

Become a Fellow of BMJ Case Reports today and you can:

- Submit as many cases as you like

- Enjoy fast sympathetic peer review and rapid publication of accepted articles

- Access all the published articles

- Re-use any of the published material for personal use and teaching without further permission

For information on Institutional Fellowships contact consortiasales@bmjgroup.com

Visit casereports.bmj.com for more articles like this and to become a Fellow 